\title{
Imprinted XIr3 (X-linked Lymphocyte Regulated 3) produces a meiosis specific protein implicated in sex chromosome gene regulation in mouse
}

\author{
Robert J Foley ${ }^{1 *}$, Seth Kasowitz², Emily Clancy', Andrew Sadowski ${ }^{1}$, Michael O'Neill ${ }^{1}$ \\ From Epigenetics and Chromatin: Interactions and processes \\ Boston, MA, USA. 11-13 March 2013
}

\section{Background}

Meiotic crossingover is an important checkpoint in almost all sexually reproducing eukaryotic organisms and is mediated by the Synaptonemal Complex (SC) during meiosis I. In this process homologous chromosomes exchange sequence information before segregating [1]. Some proteins involved in this process (i.e SYCP3) contain a conserved COR1 domain of which the function is not known, however; these proteins tend to be present only in germ cells [1-4].Xlr3 (X-linked lymphocyte regulated 3 ), an $\mathrm{X}$-linked imprinted gene in mouse, also contains a COR1 domain but has yet to be characterized.

\section{Materials and methods}

Protein and total RNA were isolated from testis sampled daily during the first wave of spermatogenesis. Gene expression was analyzed by real-time qRTPCR. Cell surface spreads were prepared by standard methods and used for immunohistochemistry.[4] Similar methods were used with embryonic ovary samples

\section{Results}

mRNA analysis shows elevated relative expression of $X l r 3$ transcripts in gonads where it becomes upregulated as the germ cells enter meiosis I. Translational analysis of XLR3 reveals the existence of a protein which is first detectable during the initiation of meiosis I. Visually, XLR3 localizes to the inactive X and Y chromosome during the pachytene stage of spermatogenesis. XLR3 localizes similarly at the sex chromosomes in female meiosis. Additionally, a second transient localization of XLR3 is seen at the post-meiotic repressed sex chromosomes (PMSC) in haploid round spermatids.

\section{Conclusions}

$X l r 3$ mRNA upregulation at the start of meiosis is consistent with initial presence of the XLR3 protein in early meiotic stage cells. Visually, XLR3 appears to localize to the inactive $\mathrm{X}$ and $\mathrm{Y}$ chromosome during meiosis $\mathrm{I}$ in males, and later to the repressed $\mathrm{X}$ or $\mathrm{Y}$ chromosomes after meiosis. This germ cell specific role is consistent with the localization of other COR1 domain proteins (i.e SYCP3, SLY, SLX). These data, taken with the unique pairing of the $\mathrm{X}$ and $\mathrm{Y}$ at meiosis, may suggest a necessary gene regulatory role of XLR3 and other COR1 domain proteins on the sex chromosomes during and after meiosis in mice.

\section{Author details}

'Department of Molecular and Cell Biology, University of Connecticut, Storrs, $C T, 06066$, USA. ${ }^{2}$ Department of Animal Biology, University of Pennsylvania School of Veterinary Medicine, Philadelphia, PA, 19104, USA.

Published: 18 March 2013

\section{References}

1. Fraune J, Schramm S, Alsheimer M, Benavente R: The mammalian synaptonemal complex: Protein components, assembly and role in meiotic recombination. Experimental Cell Research 2012, 318:1340-1346

2. Cocquet J, et al: The Multicopy Gene Sly Represses the Sex Chromosomes in the Male Mouse Germline after Meiosis. PLoS Biol 2009, 7:e1000244

3. Reynard LN, et al: Expression analysis of the mouse multi-copy X-linked gene XIr-related, meiosis-regulated (Xmr), reveals that Xmr encodes a spermatid-expressed cytoplasmic protein, SLX/XMR. Biol. Reprod 2007, 77:329-335. 
4. Tsutsumi M, et al: Characterization of a Novel Mouse Gene Encoding an SYCP3-Like Protein That Relocalizes from the XY Body to the Nucleolus During Prophase of Male Meiosis I. Biology of Reproduction 2011, 85:165-171.

doi:10.1186/1756-8935-6-S1-P19

Cite this article as: Foley et al:: Imprinted XIr3 (X-linked Lymphocyte Regulated 3) produces a meiosis specific protein implicated in sex chromosome gene regulation in mouse. Epigenetics \& Chromatin 2013 6(Suppl 1):P19.

Submit your next manuscript to BioMed Central and take full advantage of:

- Convenient online submission

- Thorough peer review

- No space constraints or color figure charges

- Immediate publication on acceptance

- Inclusion in PubMed, CAS, Scopus and Google Scholar

- Research which is freely available for redistribution

Submit your manuscript at www.biomedcentral.com/submit
C Biomed Central 